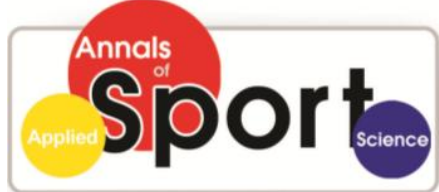

www.aassjournal.com

e-ISSN : $2322-4479$

p-ISSN : 2476-4981

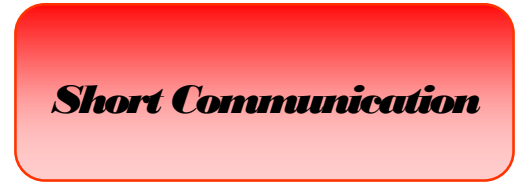

Received: 06/08/2015

Accepted: 29/09/2015

\title{
Examination on the Aggression Levels of Turkish National Skiing Athletes
}

\author{
Atalay GACAR*
}

Department of Physical Education and Sport Science, Firat University, Elazig, Turkey.

\section{BSTRACT}

Leading the aggression in some athletes ensures productivity; however, misleading does not give the same result. The aggression may reach dangerous extents. Nevertheless, aggressive behavior can be regarded as a relaxation. One of the important reasons of violence and aggression seen in sports is the belief that it increases the performance or success. Based upon these arguments, we aim to examine the aggression levels of Turkey national skiing athletes. The study has been conducted on 9 female and 11 male national skiing athletes who participated in International Alpine Skiing Cup held in Sarıamış in 2012. An assessment instrument that comprises 2 parts was used to acquire data. At the first part, demographic data of the participants were gathered; at the second part, a 30-item Aggression Scale of which reliability has been developed by İpek İlter was used to analyze the participants' aggression and factors influencing aggression. Consequently, the aggression levels were observed below the average pursuant to the gender, age and year of sports. Furthermore, assertiveness level was observed as high while disruptive and passive dimensions of aggression were found low. It is believed the athletes' being national athletes at the elite level has importance in both team success and individual success.

Key Words: Sports, Turkish National Team, Skiing, Aggression, Assertiveness.

Corresponding Author: 


\section{INTRODUCTION}

Aggression in sports may be defined as verbal or physical acts that one or some of the elements (athletes, coaches, spectators) get involved in mentioned case during the competition or bout do in order to harm the other one or attain the objective by violating the rules of sports.

There are two fundamental points to be emphasized in aggressive behaviors in sports: The first one is related to for what purpose the act of aggression is done. The second one is the target to which the act of aggression is tended. The conditions under which the games and competitions are done and the matches at which spectators present provide the ground for aggression. However, every behavior (a strike) that harms the opponent should not be regarded as aggression. The limits of aggression in sports are determined by the rules of regarded sports and the purpose behind the behavior (1).

In certain studies, it was found out that individuals who perform sports with intense aggression elements tend to behave aggressively more often while in other studies it was put forth individuals performing this kind of sports control the aggressive behaviours in an easier way and accordingly act less aggressively (2).

Disorder and concern for the future cause anxiety in individuals. This anxiety leads to aggression and violence. Aggression is an essential impulse in lives of all living creatures and instinctual behavioural pattern with biological grounds (3).

At the present time, sport is not an action aimed at only competition. Yet, it is not a factor that keeps individuals healthy. Sports stands out as actions which keep people healthy and enhance their health or maintain their healthy states. In developed countries, individuals are invited to do physical exercises to be healthy or recuperate (3).
We live together with aggression and violence in society and violence and aggression in particularly football hit the headlines almost every week. Along with attitudes and behaviours of sport managers, football coaches, coaches, referees, sports columnists and supporters, there are several historical, economic, sociological, psychological and biological reasons behind the violence and aggression seen in sports (4).

The limits of aggression in sports are determined by the rules of regarded sports and the purpose behind the behaviour.

Sportive performance is defined as motoric and psycho-motoric talents which are executed with the best potentiality in order to achieve success in a sportive action (5).

The increase in sportive aggression raises the performance of the athletes. It is argued over-arousal causes that since hyperarousal is a mean of aggression which includes hostility. The same case is seen at instrumental aggression (6). In hyperarousal, individuals show indications of nervousness, negligence along with toughness, being unable to concentrate and clumsiness (7).

As well as there are several reasons behind aggressive behaviours displayed by the athletes, they can be collected under five basic titles (8):

Athletes become more aggressive if:

*the athlete of team is losing the match

*they have a feeling the referee or referees conduct the match in an improper way

* they are surprised

*they suffer because of any physical contact or injury

*they perform under their capacity (8).

Apart from aforementioned factors, several conditions related to competition may lead to aggression in some way. These are (8): 
*Temperature: Aggressive behaviours increase at the matches held when weather temperature is high.

*The score: When the difference between the score of the teams is high, aggression is seen at the highest level. However, if the score is close, aggression is at its lowest level.

*Playing at home or away: The teams playing away play more aggressively than the home team.

*The match result: At the end of the match, losing teams act more aggressively than the winning teams.

*Athletes' or Teams' Score at the League: The teams are at lower ranks at the league tend to act more aggressively when they play with a team that is above themselves at the list.

*The stages of the match: While it is seen less aggressive behaviours at the first half, they increase at the second half. The losing team acts more aggressively at the half of the game though the winning team enacts aggressive behaviours at the end of the game (8).

For attempts to prevent aggression and violence in sport, it is a must to know origin of the aggression; to take responsibilities as coach, athlete and club managers; to avoid broadcasting that will cause aggression as Media Company; to support education for spectator, supporter and so society to behave within fair-play rules. (9).

In our study, it is aimed to examine aggression level of Turkish national ski athletes based upon these importance and thoughts.

\section{MATERIALS AND METHODS}

Participants. In our study, 9 female and 11 male ski athletes who attended International Alpine Skiing Discipline Sarikamiş Cup in 2012 and were from Turkish national ski team constitute subject group.
Tools. In the study, personal data form (gender, age, year of sports) was used in order to gather information about Turkish national ski team athletes and aggressiveness inventory whose reliability was developed by İpek İlter KİPER (1984) and which consists of 30 items was used in order to specify athletes' aggression level (10).

Aggression Scale (í.İ.A.S). Aggression scale developed by İpek ILTER (KİPER) was used in this study. This inventory was implemented to Turkish national ski team athletes as a group. Scale includes three subtests which consist of 30 items. These are destructive aggression, impulsive aggression and passive aggression. Each sub-test was determined by 10 questions. The items 1, 2, $3,13,14,15,22,23,24,29$ are about destructive aggression, the items $4,5,6,10$, $11,12,19,20,21,28$ are about impulsive aggression and the items 7, 8, 9,16, 17, 18, $25,26,27,30$ are about passive aggression. Questions are seven-point Likert scale that includes answers from "it does not suit me at all" to "it suits me a lot". Theoretically in every sub-test, the subject who answers every question as 'it suits me a lot' gets +30 points and the subject who answers the question as 'it does not suit me at all' gets -30 points. Nevertheless, because minus points cannot be used statistically and it is thought that 'zero' will be a problem at statistical analysis; 31 points are added to every total point. Thus, the lowest point taken from each sub-test is 1 and the highest point is 61 . A general aggressiveness point is also achieved on the basis of total points of every three scales for every subject even if there is not any general aggressiveness point at inventory (11).

Statistical Analysis. Frequency distribution, arithmetic mean, percentages, independent sample t-test and One-Way ANOVA with Tukey posthoc test was used to analyze data. Data was analyzed using SPSS software. A level of 0.05 was considered significant. 


\section{RESULTS}

Nine female (45\%) and 11 male (55\%) ski athletes who attended International Alpine Skiing Discipline Sarikamiş Cup in 2012 and were from Turkish national ski team athletes constitutes subject group.

In table 1, 2, and 3, when the analysis results with regard to the points of aggression scale as to variable of Turkish national ski team athletes' gender, age, and years of sports history, respectively, were examined, it was stated that there was not significant differentiation in terms of gender, age, and years of sports history variables, respectively, from sub-dimensions of general aggressiveness and aggression levels $(\mathrm{p}<0.05)$.

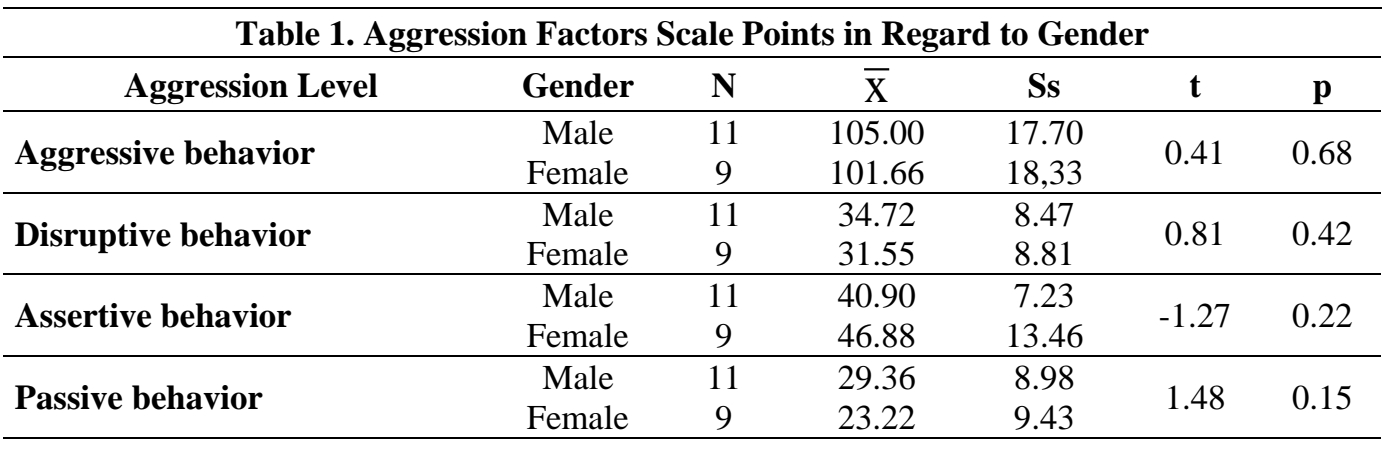

\begin{tabular}{|c|c|c|c|c|c|c|}
\hline \multicolumn{7}{|c|}{ Table 2. Aggression and it's Factors Scale Points as to Age } \\
\hline Aggression Level & Age & $\mathbf{N}$ & $\overline{\mathrm{X}}$ & Ss & $\mathbf{F}$ & $\mathbf{p}$ \\
\hline \multirow{4}{*}{ Aggressive behavior } & 17-19 Years & 8 & 100.87 & 19.40 & \multirow{3}{*}{0.19} & \multirow{3}{*}{0.82} \\
\hline & 20-22 Years & 8 & 106.50 & 12.05 & & \\
\hline & 23-28 Years & 4 & 102.75 & 26.42 & & \\
\hline & Total & 20 & 103.50 & 17.58 & & \\
\hline \multirow{4}{*}{ Disruptive behavior } & 17-19 Years & 8 & 32.00 & 8.97 & \multirow{3}{*}{0.94} & \multirow{3}{*}{0.40} \\
\hline & 20-22 Years & 8 & 36.37 & 7.68 & & \\
\hline & 23-28 Years & 4 & 29.75 & 9.53 & & \\
\hline & Total & 20 & 33.30 & 8.55 & & \\
\hline \multirow{4}{*}{ Assertive behavior } & 17-19 Years & 8 & 42.87 & 12.06 & \multirow{3}{*}{0.95} & \multirow{3}{*}{0.40} \\
\hline & 20-22 Years & 8 & 41.12 & 9.94 & & \\
\hline & 23-28 Years & 4 & 50.00 & 8.60 & & \\
\hline & Total & 20 & 43.60 & 10.63 & & \\
\hline \multirow{4}{*}{ Passive behavior } & 17-19 Years & 8 & 26.00 & 8.03 & \multirow{3}{*}{0.53} & \multirow{3}{*}{0.59} \\
\hline & 20-22 Years & 8 & 29.00 & 8.81 & & \\
\hline & 23-28 Years & 4 & 23.00 & 14.23 & & \\
\hline & Total & 20 & 26.60 & 9.47 & & \\
\hline
\end{tabular}

\section{DISCUSSION AND CONCLUSION}

In this part, the findings about whether sub-scales of general aggressiveness levels and aggression levels of Turkish national ski team athletes who were research sample shows any differentiation or not as to some variables was discussed and interpreted. It is thought that being national team athletes at elite level have importance for both team success and individual success as psychological mindedness.

According to research findings, when the gathered points for destructive aggression, impulsive aggression, passive aggression 
and general aggressiveness levels of the subjects with relation to aggression state are examined, it is observed that impulsive behavior levels are higher than passive and destructive behavior points. Different studies support our study, as well. $(12,13,14,15,16,17,18$,$) When the points of$ Turkish national ski team male and female subjects in terms of general aggressiveness and aggression sub-dimensions are examined, any significant difference between males and females cannot be ascertained statistically. It can be concluded that male subjects have higher points at general aggressiveness, destructive aggression and passive aggression; even if there is not so significant difference at impulsive aggression, female subjects have higher points $(\mathrm{p}<0.05)$. Similar to this study, the studies of Soykan (1993), Kopper (1996), Tiryaki 1996, Scharf (2000), Giles and Heyman (2005), Yildiz S. (2009) support our study by showing similarity to research findings $(19,20,21,22,23,11)$.

\begin{tabular}{|c|c|c|c|c|c|c|}
\hline \multicolumn{7}{|c|}{ Table 3. Aggression and it's Factors Scale Points as to Years of Sports History } \\
\hline Aggression Level & Year of Sports & $\mathbf{N}$ & $\overline{\mathrm{X}}$ & Ss & $\mathbf{F}$ & $\mathbf{p}$ \\
\hline \multirow{3}{*}{ Aggressive behaviour } & 7-10 Years & 8 & 100.87 & 19.40 & \multirow{3}{*}{0.19} & \multirow{3}{*}{0.82} \\
\hline & 11-14 Years & 8 & 106.50 & 12.05 & & \\
\hline & 15 Years and over & 4 & 102.75 & 26.42 & & \\
\hline \multirow{4}{*}{ Disruptive behaviour } & Total & 20 & 103.50 & 17.58 & \multirow{4}{*}{0.94} & \multirow{4}{*}{0.40} \\
\hline & 7-10 Years & 8 & 32.00 & 8.97 & & \\
\hline & 11-14 Years & 8 & 36.37 & 7.68 & & \\
\hline & 15 Years and over & 4 & 29.75 & 9.53 & & \\
\hline \multirow{4}{*}{ Assertive behaviour } & Total & 20 & 33.30 & 8.55 & & \\
\hline & 7-10 Years & 8 & 42.87 & 12.06 & \multirow{3}{*}{0.95} & \multirow{3}{*}{0.40} \\
\hline & 11-14 Years & 8 & 41.12 & 9.94 & & \\
\hline & 15 Years and over & 4 & 50.00 & 8.60 & & \\
\hline \multirow{5}{*}{ Passive behavior } & Total & 20 & 43.60 & 10.63 & \multirow{4}{*}{0.53} & \multirow{4}{*}{0.59} \\
\hline & 7-10 Years & 8 & 26.00 & 8.03 & & \\
\hline & 11-14 Years & 8 & 29.00 & 8.81 & & \\
\hline & 15 Years and over & 4 & 23.00 & 14.23 & & \\
\hline & Total & 20 & 26.60 & 9.47 & & \\
\hline
\end{tabular}

When the aggressiveness points of Turkish national ski team athletes in terms of age groups are examined, any statistical difference cannot be identified in term of general aggressiveness and aggression subdimension. It can be stated that general aggressiveness, destructive behavior and passive behavior points are lower; even if there is no significant difference, impulsive behavior points are higher than average $(\mathrm{p}<0.05)$. The researches that were made by Yildiz S. (2009), Topuz and colleagues (2010) and showed similarity to our research support our study $(11,18)$.

When analysis results with regard to aggression scale points as to year of sports of Turkish national ski team athletes, it was found that there is not any significant difference in terms of year of sports from sub-dimension of general aggressiveness and aggression level $(\mathrm{p}<0.05)$. However, it is observed that as year of sports increases; destructive and passive behavior level decrease and impulsive behavior level increases. As a different research, the study of Bilge (1990) and Karakaya (2002) supports our study $(13,12)$.

As a result, it is observed that while general aggressiveness levels and destructive behavior and passive behavior levels from sub-dimensions of aggression of Turkish national ski team athletes who attended our 
study are lower, their impulsive behavior levels are high. Our study which are directly similar to our hypothesizes and also different studies showed that sport is a tool that contributes not only physical and mental development but also psychological development, as well. One of the most important reasons for violence and aggression cases in sport is the belief that this will increase performance and success. It is believed that our study will be a supportive study for upcoming studies.

\section{APPLICABLE REMARKS}

- Having an important role in the formation of performance psychology, should be given work in the training level for national team athletes to be successful.

- It could be think that; our study will be referring to other studies in the area.

\section{REFFRENCES}

1. Acet M. ( 2003). Aggression in Sport and Its Severity, İstanbul, Morpa Publishing., 55-56.

2. Eripek S. (1993). Sports Psychology. Eskişehir, Anadolu University Publishing, 77-281.

3. Balcioğlu İ. (2003). Sociology and Psychology of Sport. İstanbul, Bilge Publishing, 132-133.

4. Konter E. (2006). A Sports Psychology Manual. Ankara, Nobel Publishing and Distribution, 72-144.

5. Hasırcı S. (2000). Locus of Control in Sports. Bağırgan Press. Ankara.

6. Cox RH. (1985). Sport psychology. Dubuque, lowo: Wm.C. Brown

7. Konter E. (1996). A Trainer as a Leader. Alfa Printing Publishing and Distribution. İstanbul

8. Tiryaki Ş. (2000). Sports Psychology. Ankara, Eylül Publishing, 3-153.

9. Doğan O.(1993). Sport psychology. Adana, Nobel Bookstore, 2nd edition, 49-128.

10. Kiper İI. (1984). The Relation of Aggression Types To Various Economic, Social and Academic Variables. Ankara, Ankara University. Master's Thesis,

11. Yildız S. (2009). Examination on the Aggression Levels of Secondary School Students who Do and Do not Exercise. T.R. Selçuk University Institute of Health Sciences. Faculty of Physical Education and Sports Teaching. Master's Thesis. Konya.

12. Karakaya MA. (2002). Comparison of the Aggression Levels of the Athletes Who Perform Team Sports and the Ones Who Perform Individual Sports (Sample of N.U. Aksaray SPES). Niğde, Niğde University, Master's Thesis, 3-39

13. Bilge F. (1990). Psychological Needs of Sportsperson. Ankara Hacettepe University Institute of Social Sciences, Master's Thesis.

14. Ürküt G. (1988). Examination on the Aggressive Reactions That College Students from Different SocioEconomic and Gender Groups Develop Towards Frustration Through Rosenzweig Picture-Frustration Test and Comparison of the Groups in terms of the Direction and Type of Agression. Bursa,Uludağ University Master's Thesis,.

15. Duncan RD. (1999), Peer and Sibling Aggression: An investigation of into-and Extra-Familial Bullying. Journal of Interpersonal Violence, Aug . Vol:14., s.871-886.

16. Aktaş Z, Çobanoğlu G, Yazıcılar, i.(2004). Examination of the Relationship Between Aggression Level of Professional Male Basketball Players and Their Game Success. Spormetre, Physical Education and Sports Sciences Magazine, II (3) 127-134.

17. Güner BÇ.(2006). Examination of Aggression Level of Sportsperson Who Does Team Sports and Individual Sports. Unpublished Master's Thesis. Ondokuz Mayıs University.

18. Topuz R, Sanioğlu A, Çağlayan HS. (2010). Examination on the Aggression Levels of Amateur Football Players, Selçuk University Journal of Physical Education and Sports Science, 12 (1), 42-49.

19. Soykan F. (1993). Woman and Violence in Turkish Cinema., 3P:Psychiatry, Psychology, Psychopharmacology Journal, 1 (4) 21-32.

20. Kopper BA.(1996). Epperson DL. The experience and expression of anger: Relationships with gender, gender role socialization, depression, and mental health function. Journal of Counseling Psychology, (43), 158-165. Samsun.

21. Tiryaki Ş. (1996). Determination of the Aggression Levels of Individuals who Do Exercise. Mersin, Mersin University, Master's Thesis, 12. 
22. Scharf SC. (2000). Gender differences in adolescent aggression: an analysis of instrumentality vs. expressiveness, Unpublished Doctoral Thesis Michigan University Department of Clinical Psychology, Michigan.

23. Giles J, Heyman GD. (2005). "Young Children's Beliefs About The Relationship Between Gender and Aggressive Behavior" Child Development. January/February. Vol: 76. No: 1. s.107 - 121.

GACAR, A. (2015). Ann Appl Sport Sci, 3(3): 01-08. 


\section{تازههاى علوم كاربردى ورزش \\ دوره سوم، شماره سوم

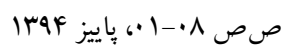 \\ مقاله كوتاه \\ تاريخ دريافت: مقاه كوتاه

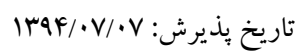 \\ بروسى سطوح يرخاشَّى ورزشكاران ملى اسكى تر كيه

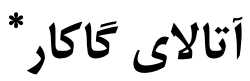

استاديار گروه تربيت بدنى و علوم ورزشى، دانشخاه فيرات، ايلازيخ، تر كيه.

\section{جكيده}

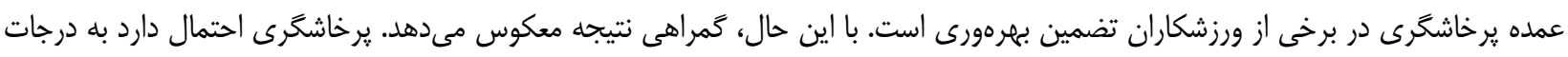

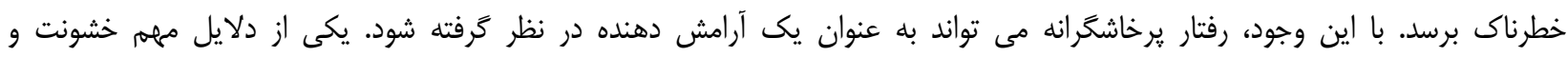

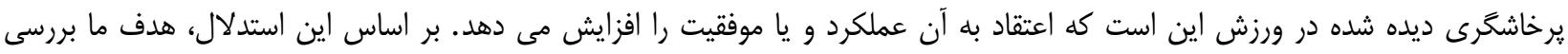

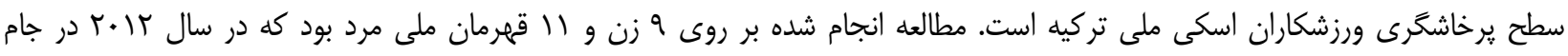

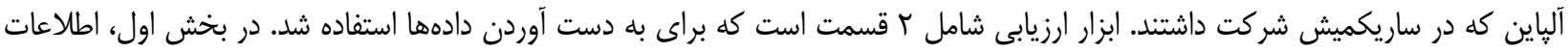

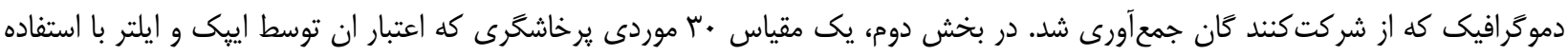

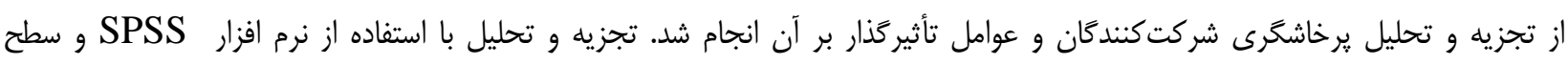

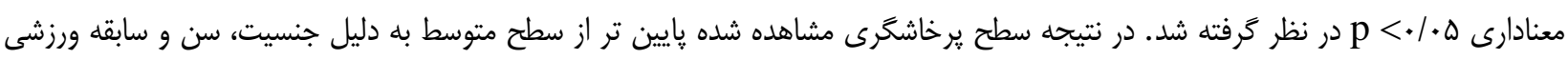

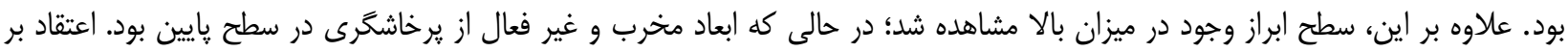

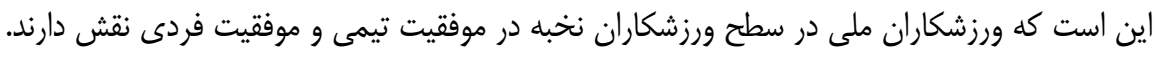

وازَّان كليدى: ورزش، تيم ملى تركيه، اسكى، يرخاشكَى، ابراز وجود.

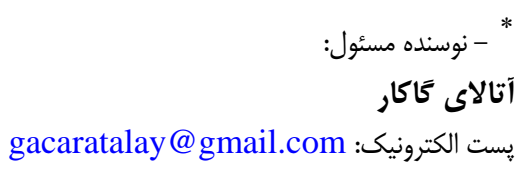

